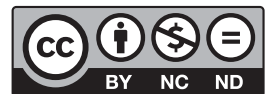

Estudos Teológicos foi licenciado com uma Licença Creative Commons Atribuição - NãoComercial - SemDerivados 3.0 Não Adaptada

http://dx.doi.org/10.22351/et.v60i1.3662

\title{
O PRINCÍPIO PLURALISTA, CORPOREIDADE E SEXUALIDADE ${ }^{1}$
}

\author{
The pluralist principle, embodiment and sexuality
}

\section{Claudio de Oliveira Ribeiro ${ }^{2}$}

Resumo: A pesquisa identifica bases conceituais que introduzem criticamente na teologia latino-americana o valor de dimensões antropológicas que estão em torno da corporeidade, da sexualidade e do prazer, em geral desprezadas pelas leituras teológicas hegemônicas. Metodologicamente, foi estabelecida a interação do princípio pluralista com a produção teológica feminista e queer latino-americanas, especialmente as de Ivone Gebara, Marcella Althaus-Reid e André Musskopf, e com a teopoética de Rubem Alves. Entre os resultados apresentados destaca-se o fato da reflexão teológica sobre corporeidade, sexualidade e prazer ter seu histórico na contribuição das teologias feministas e queer, sobretudo as formuladas no contexto latino-americano. $\mathrm{O}$ debate mostra que as definições acerca do corpo e das práticas sexuais, explícitas ou não, quer sejam vivenciadas em contextos de prazer, autenticidade, afeto e festividade, quer em formas sublimadas, repressivas e violentas, são bases constituintes e definidores da realidade e se revelam nas fronteiras e nos entrelugares das culturas. Daí a importância delas para a reflexão teológica dentro do princípio pluralista.

Palavras-chave: Teologia feminista. Teologia queer. Princípio pluralista. Corporeidade. Sexualidade.

Abstract: The research identifies conceptual bases that critically introduce in Latin American theology the value of anthropological dimensions that are around embodiment, sexuality and pleasure, generally disregarded by the hegemonic theological readings. Methodologically, the interaction of the pluralistic principle with Latin American feminist and queer theological production, especially those of Ivone Gebara, Marcella Althaus-Reid and André Musskopf, and the theopoetics of Rubem Alves, was established. Among the results presented is the fact that theological reflection on embodiment, sexuality and pleasure has its history in the contribution of feminist and queer theologies, especially those formulated in the Latin American context. The debate shows that definitions about the body and sexual practices, explicit or not, whether experienced in contexts of pleasure, authenticity, affection and festivity, or in sublimated, repressive and violent forms, are constitutive and definitive bases of reality and reveal themselves at the borders and in between spaces of cultures. Hence their importance for theological reflection within the pluralistic principle.

Keywords: Feminist Theology. Queer Theology. Pluralist Principle. Embodiment. Sexuality.

1 O artigo foi recebido em 05 de maio de 2019 e aprovado em 13 de agosto de 2019 com base nas avaliações dos pareceristas ad hoc.

2 Doutor em Teologia. Professor visitante do Programa de Pós-Graduação em Ciência da Religião da Universidade Federal de Juiz de Fora/MG. E-mail: cdeoliveiraribeiro@gmail.com 


\section{Introdução}

A teologia latino-americana, ao longo do seu desenvolvimento nas últimas décadas do século 20, mas também nas primeiras deste século, priorizou a dimensão política para suas interpretações e nem sempre esteve atenta às diferenças culturais, fortemente híbridas e entrecruzadas com a diversidade das expressões religiosas. Em nossas análises, temos destacado que a teologia latino-americana também não esteve devidamente atenta ao pluralismo religioso nem às demandas da vida que surgem na realidade do cotidiano e às dimensões fundamentais da vida humana como a corporeidade, a sexualidade e os aspectos das experiências lúdicas. ${ }^{3}$ Em nossas pesquisas sobre o princípio pluralista, temos trabalhado, ainda que com limitações, na direção de tentar responder a essas demandas.

Neste artigo, devido à necessidade de delimitação temática, apresentaremos a parcela de resultados que realça a reflexão teológica sobre corporeidade, sexualidade e prazer. Ela tem seu histórico na contribuição singular e efetiva das teologias feministas, sobretudo as formuladas no contexto latino-americano. Nossa compreensão é que toda e qualquer reflexão teológica em torno desses aspectos deve iniciar com um tributo ao salto qualitativo e crítico dado pelas teologias feministas nessa reflexão, sempre acompanhadas de indicações políticas concretas feitas pelos movimentos feministas.

Diante dos esforços em forjar e garantir o referido legado teológico latino-americano, há desafios enormes que marcam o contexto atual. Não obstante as muitas e diversificadas análises, reconhecemos que não é tarefa simples indicar tais desafios. Há, no entanto, três aspectos que têm mobilizado a atenção de teólogos e teólogas. O primeiro deles é a tarefa de alargamento metodológico e de atualização nas formas de compreensão da realidade, pressuposto sempre presente nas teologias de caráter social e político. No caso latino-americano, trata-se de avaliar o peso dos esquemas reducionistas que utilizaram em demasia a bipolaridade "dominantes x dominados" devido à influência de certas formas de marxismo nas análises sociais, ocultando por vezes a complexidade social.

Um segundo desafio está em torno das questões relativas à emergência das subjetividades na atualidade. Essa dimensão se conecta com aspectos da espiritualidade. Não foram poucas as vezes em que a teologia da libertação, por exemplo, foi acusada de "não ter espiritualidade". É fato que as dimensões racionais presentes no método teológico latino-americano, como as mediações socioanalíticas para a compreensão da realidade, o rigor científico nas exegeses bíblicas e nas avaliações históricas e as formas articuladas e planejadas de ação eclesial e política, marcam uma ambientação de racionalidade que talvez possam inibir formas mais subjetivas e espontâneas de espiritualidade. No entanto, tais questões, pela complexidade delas, precisam ser mais bem compreendidas e aprofundadas.

3 Cf. RIBEIRO, Claudio de Oliveira. Testemunho e Libertação: a teologia latino-americana em questão. São Paulo: Fonte Editorial, 2016. 
Um terceiro desafio reside em torno dos encontros e desencontros da teologia com a pluralidade. Diante da teologia latino-americana está a tarefa de aprofundar seus esforços, mesmo com suas limitações e ambiguidades, refletir sobre as demandas que a sociedade apresenta e que recaem sobre o quadro de pluralismo, seja o que está em torno das questões do método teológico, do quadro religioso ou de questões de natureza antropológica. Essas últimas podem ser exemplificadas na capacidade de alteridade ecumênica, nas formas autênticas de espiritualidades integradoras, inclusivas e ecológicas, e no valor da corporeidade, da sexualidade e da dimensão lúdica na reflexão teológica e nas ações concretas de afirmação da vida.

A formulação do princípio pluralista, como veremos em síntese a seguir, tem sido efetuada a partir do enfrentamento desses três desafios, interligados entre eles, que emergem do quadro teológico latino-americano. ${ }^{4} \mathrm{O}$ que a dimensão da corporeidade e da sexualidade representa para o pensar teológico está ligado a esses três fatores, sobretudo aos dois últimos: as tensões entre racionalidade e subjetividade humanas, e a valorização da pluralidade no campo antropológico.

Apresentaremos os resultados da pesquisa em quatro momentos. O primeiro, oferecendo uma síntese do que temos denominado o princípio pluralista. O segundo, mostrando que as definições acerca do corpo e das práticas sexuais são materiais constituintes e definidores da realidade e, devido a isso, possuem forte valor teológico. O terceiro, destacando formas de espiritualidades que expressam as mudanças e os processos do corpo, o que realça novas possibilidades de autoafirmação das pessoas e de grupos envolvidos e, ao mesmo tempo, reforça horizontes mais amplos para as indicações de compromissos sociais e atividades políticas. Por fim, algumas indicações metodológicas que visem atenuar a supremacia da dimensão conceitual em detrimento da concretude da vida que tem marcado os processos de reflexão e de educação teológica e mostrem caminhos para uma metodologia capaz de articular a dimensão corpórea com o conjunto da reflexão teológica.

\section{O princípio pluralista}

O princípio pluralista é um instrumento hermenêutico de mediação analítica e teológica da realidade sociocultural e religiosa que procura dar visibilidade a experiências, grupos e posicionamentos que são gerados nos entrelugares, bordas e fronteiras das culturas e das esferas de institucionalidades. Ele possibilita divergências e convergências novas, outros pontos de vistas, perspectivas críticas e autocríticas para diálogo, empoderamento de grupos e de visões subalternas e formas de alteridade e de inclusão, considerados e explicitados os diferenciais de poder presentes na sociedade.

Não se trata apenas de uma indicação ética ou "catequética". Com o princípio pluralista, as análises tornam-se mais consistentes, uma vez que possibilitam melhor

\footnotetext{
4 Para isso, veja dois artigos onde apresento a noção de princípio pluralista: O Princípio pluralista: bases teóricas, conceituais e possibilidades de aplicação. Revista de Cultura Teológica, XXV, n. 90, p. 234-257, 2017; e O Princípio pluralista. Cadernos de Teologia Pública-IHU, XVI, v. 14, n. 128, 2017.
} 
identificação do "outro", não idealizado, mas concretamente identificado, especialmente as pessoas e grupos que são invisibilizados dentro da visão sociológica que Boaventura de Sousa Santos chamou de "sociologia das ausências"s. A sensibilidade com as distintas expressões culturais ou religiosas, majoritárias ou minoritárias, fronteiriças ou não, contribui para uma "sociologia das emergências" de novos rostos, variados perfis religiosos, multiplicidades de olhares, perspectivas e formas plurais de atuação. Com essa perspectiva "policromática", os esforços de análise do presente ou os de identificar os futuros das religiões poderiam encontrar maior êxito.

Seguimos a concepção de entrelugar, como trabalho fronteiriço da cultura, conforme nos indica Homi Bhabha ${ }^{6}$, que requer um encontro com "o novo" que não seja mera reprodução ou continuidade de passado e presente. Para nossas reflexões, especialmente no que comumente nos referimos à necessidade de alargamento de horizontes metodológicos para o estudo da religião, consideramos que o "local da cultura" [para usar o sugestivo título da obra] é fundamental no processo que advogamos de estabelecer mediações socioanalíticas para as interpretações teológicas e, também, para as análises científicas da religião em geral. O conceito entrelugar está relacionado à visão e ao modo como grupos subalternos se posicionam frente ao poder e como realizam estratégias de empoderamento. Tais posicionamentos geram entrelugares, especialmente experimentados nas malhas do cotidiano, em que aparecem com maior nitidez questões de âmbito comunitário, social e político. A posição de fronteira permite maior visibilidade das estruturas de poder e de saber, o que pode ajudar na apreensão das subjetividades de povos subalternos.

O princípio pluralista está arquitetado sob a noção de entrelugares da cultura e estabelecido também sob outras duas grandezas - alteridade e ecumenicidade. Ele visa reforçar as experiências religiosas e culturais que se constituem como aprofundamento dos processos de humanização, da democracia, da cidadania, e da capacidade contra-hegemônica na defesa de direitos humanos e da terra. O mesmo é possível afirmar em relação à necessidade de tais experiências serem vistas e analisadas considerando-se as relações assimétricas de poder presentes na sociedade e as formas de colonialidade. Em ambos os casos, alteridade e visão ecumênica são chaves significativas de interpretação do quadro de pluralismo religioso e do pluralismo antropológico nele presente, que visibiliza formas plurais da sexualidade e do prazer.

Nossas análises se inserem no que se tem denominado perspectiva ou giro decolonial. Trata-se de esforços com um sentido estratégico que revela interpelações políticas e epistemológicas de reconstrução de culturas, instituições e relações sociais, tendo em perspectiva o empoderamento de grupos subalternos e construções críticas alternativas e plurais de novos modelos sociais.

Seguimos a perspectiva dos estudos culturais, que em solo latino-americano ganhou, a partir dos estudos, sobretudo do peruano Anibal Quijano e dos argentinos Enrique Dusssel e Walter Mignollo, um novo conteúdo crítico. Tais interpelações crí-

SANTOS, Boaventura de Sousa. A gramática do tempo: para uma nova cultura política. São Paulo: Cortez, 2010.

6 Cf. BHABHA, Homi. O Local da Cultura. Belo Horizonte: UFMG, 2001. 
ticas são marcadas por certo caráter propositivo e prático e por ações concretas no âmbito cultural e político. O "decolonial" indica uma desobediência epistemológica sem a qual "não será possível o desencadeamento epistêmico e, portanto, permaneceremos no domínio da oposição interna aos conceitos modernos e eurocentrados, enraizados nas categorias de conceitos gregos e latinos e nas experiências e subjetividades formadas dessas bases" ". A tarefa decolonial consiste em construir a vida a partir de outras categorias de pensamento que estão além dos pensamentos ocidentais dominadores. Trata-se de uma postura e atitudes permanentes de transgressão e de intervenção no campo político e cultural, na incidência das culturas subalternalizadas e invisibilizadas, nas quais se podem identificar, visibilizar e incentivar lugares de exterioridade e de construções críticas alternativas e plurais. "O paradigma decolonial luta por fomentar a divulgação de outra interpretação que põe em evidência uma visão silenciada dos acontecimentos" e, ao mesmo tempo, revela "os limites de uma ideologia imperial que se apresenta como a verdadeira e única interpretação"s.

O princípio pluralista está em sintonia com as proposições conceituais desses estudos que visam realçar a decolonialidade do poder, do saber e do ser. ${ }^{9}$ Com isso, as aproximações religiosas e a valorização do pluralismo podem ser, não somente percebidas, e ter suas tendências identificadas nas análises, mas elas podem ser sobretudo construídas. É fato que tal empreendimento é tarefa dos próprios grupos religiosos e da interação deles na sociedade, mas os estudos de religião podem cooperar oferecendo análises cujas bases sejam sólidas e, ao mesmo tempo, criativas e indicadoras de novos caminhos. Nossa intenção em articular o princípio pluralista com análises sobre o pluralismo antropológico se fundamenta, entre outros aspectos, na necessidade de se responder à essa tríplice demanda em torno da decolonialidade.

Consideramos que o princípio pluralista, obviamente articulado com outros instrumentos de análise, pode representar uma das contribuições relevantes para esse desafio acima indicado. Nesta análise, buscamos os pontos de identificação desse princípio com as questões relativas à corporeidade, à sexualidade e ao prazer pautadas por setores latino-americanos das teologias feministas e queer.

\section{A dimensão da corporeidade, da sexualidade e do prazer}

Por variadas razões, temos enfatizado em nossa pesquisa as elaborações feitas pela teóloga católica Ivone Gebara e pela teóloga protestante Marcella Althaus-Reid. Ambas enfatizam a concepção de que as definições acerca do corpo e das práticas sexuais, explícitas ou não, vivenciadas num contexto libertador de prazer, autenticidade e afeto ou em formas sublimadas, repressivas e violentas, são materiais constituintes

${ }^{7}$ MIGNOLO, Walter. Desobediência epistêmica: a opção descolonial e o significado de identidade em política. Cadernos de Letras da UFF - Dossiê: literatura, língua e identidade, Niterói, n. 34, p. 288, 2008.

${ }^{8}$ MIGNOLO, Walter. Delinking. The rhetoric of modernity, the logic of coloniality and the grammar of decoloniality. Cultural studies, Abingdon-on-Thames: Routledge, v. 2 and 3, n. 21, March/May 2007. p. 457.

9 Cf. MIGNOLO, Walter. Histórias locais - Projetos globais: colonialidade, saberes subalternos e pensamento liminar. Belo Horizonte: UFMG, 2003. 
e definidores da realidade e da conexão dela com a vida em geral, em seus aspectos políticos, antropológicos e cósmicos. Para Gebara,

O movimento feminista na sua diversidade foi e é um movimento de "direitos humanos" e se pauta fundamentalmente por uma agenda de direitos a partir do corpo como realidade singular e plural em busca de liberdade. Dizer corpo significa dizer, nos feminismos, direito dos corpos. Todas nós vivemos, nos movemos, trabalhamos e amamos como corpos. O feminismo é um olhar específico a partir do corpo e para o corpo das mulheres, um olhar crítico em relação aos lugares que ocupamos, às obrigações que nos impuseram e aos sonhos que nutrimos. Por isso, questões relativas à sexualidade, à maternidade voluntária, à luta contra a violência doméstica e à liberdade de opção sexual são reinvindicações culturais, políticas e sociais que vislumbram outro tratamento e outra compreensão filosófica de nossos $\operatorname{corpos}^{10}$.

Algo similar devemos dizer no tocante à teologia queer, que possui também em Marcella Althaus-Reid e, mais recentemente no Brasil, em André Musskopf uma original contribuição. Queer é uma categoria inclusiva de todas as sexualidades não heterossexuais. A teoria queer relaciona vários aspectos da vida social, inclusive setores não pensados como sexualizados, como, por exemplo, a economia e a política. Althaus-Reid e Musskopf falam a partir de lugares específicos, no caso a diversidade sexual, mas também a partir de outras vivências de superação da subalternidade, o que lhes confere legitimidade e autenticidade à reflexão efetuada. As reflexões que fazem realçam como a teologia é um espaço ocupado predominantemente pela rigidez do patriarcado e da heteronormatividade e que pouca ou nenhuma visibilidade tem sido dada às mulheres, às pessoas do grupo LGBTI+ (lésbicas, gays, bissexuais, transexuais, intersexuais) e à maneira como ambos vivenciam as experiências religiosas. Musskopf enfatiza que

[...] ao mesmo tempo em que explodiam a Teologia da Libertação e a Teologia Feminista, explodia também o Movimento Gay, dando os seus primeiros passos na busca por direitos iguais também para gays e lésbicas.

Mesmo assim, o despontar deste novo sujeito teológico não teve reflexos dentro da igreja e da teologia da mesma forma como o tiveram a Teologia da Libertação, com sua opção preferencial pelos pobres, e a Teologia Feminista, com a valorização do potencial das mulheres ${ }^{11}$.

Ao nos referirmos a esse autor e a essas autoras, desejamos valorizar e acentuar a produção que apresentam, reconhecer a importância dela e construir nossa argumentação a partir do lugar da heterossexualidade, mas procurando desconstruir formas de heteronormatividade e de legitimação de machismos, heterossexismos e androcentrismos.

Também ocupa lugar especial em nossas reflexões o pensamento de Rubem Alves. A recriação da linguagem teológica que ele fez com a teopoética, a introdução

${ }^{10}$ GEBARA, Ivone. Mulheres, religião e poder: ensaios feministas. São Paulo: Terceira Via, 2017.

${ }^{11}$ MUSSKOPF, André Sidney. Uma brecha no armário: propostas para uma teologia gay. São Paulo: Fonte Editorial; São Leopoldo: CEBI, 2015. p. 24. 
do elemento simbólico-poético como tradução das concepções teológicas fundamentais da fé, a forma criativa e provocativa com a qual elaborou sua teologia, em especial na valorização das dimensões da corporeidade, da sexualidade e do prazer, são razões para recorrermos ao pensamento dele.

De posse de algumas indicações feitas por esses autores e autoras, realçaremos como o princípio pluralista, ao mesmo tempo: i) está presente nessas perspectivas, sobretudo pela lógica de empoderamento de grupos subalternos, pela valorização da pluralidade das experiências, boa parte delas vividas nos entrelugares das culturas que incidem no cotidiano das pessoas, e pela visão crítica e propositiva delas; ii) é devedor dessas visões teológicas críticas e criativas, e iii) pode ser, ainda que modestamente, um elemento de aprofundamento de tais perspectivas. Tal interação segue na perspectiva das proposições conceituais dos estudos culturais decoloniais em realçar a decolonialidade do poder, do saber e do ser. Nossa insistência em articular o princípio pluralista com análises sobre dimensões antropológicas - e não somente sobre o pluralismo religioso -, se fundamenta na necessidade de se responder a essa tríplice demanda em torno da decolonialidade.

\section{$O$ corpo entre o prazer e a dor}

Se estabelecermos como referência o quadro plural das espiritualidades contemporâneas, perceberemos que nele emergem diferentes formas e experiências centradas nas realidades que são corporificadas no cotidiano. Ou seja, elas ganham expressão na corporeidade. Isso se dá tanto nas dimensões de prazer como nas de dor, sejam elas expressas nas vidas pessoais e ordinárias ou coletivamente nas dinâmicas sociais de autoafirmação e empoderamento. Essas experiências, em sua maioria, residem nos entrelugares da cultura, marcadas por gozo e prazer, mas também pela dor e frustração, e são, ao mesmo tempo, conectadas às possibilidades de compromisso social e atividade política a partir de complexos processos de negociação cultural.

Neste sentido, o princípio pluralista, devido às suas bases conceituais associadas à antropologia, é fundamental para as análises. Rubem Alves, por exemplo, nos chamara a atenção que "o corpo não está em busca da verdade objetiva que mora com a ciência, mas da verdade gostosa e erótica que vive com a sápida-ciência, sapiência, ciência saborosa, ciência que tem a ver com viver e morrer"12. Por sua vez, Ivone Gebara já indicara que "somos um corpo uno e múltiplo, nossos olhares e análises são igualmente múltiplos, assim como é múltiplo o nosso sentir o mundo"13. Dessas formas de espiritualidades surgem as possibilidades de afirmação do corpo, tanto em seu poder erótico como em seu poder criativo de dar e recriar a vida e de ser fonte de cura, felicidade e sentido de vida. Nessa perspectiva, a teologia feminista realça a pergunta "O que é mesmo meu corpo?" e procura respostas que revelam profundas dimensões políticas no controle dos corpos:

\footnotetext{
12 ALVES, Rubem. Variações entre a vida e a morte: a teologia e sua fala. São Paulo: Paulinas, 1982. p. 78.

13 GEBARA, 2017, p. 208.
} 
Meu corpo sou eu, minha história, minhas circunstâncias, minhas escolhas, meus pensamentos, meus medos, meus erros, meus prazeres e minhas dores. Hoje dizemos isso, embora saibamos que a grande maioria dos corpos de mulheres continua sendo definida a partir dos corpos masculinos dos corpos de poder, das autoridades políticas, dos líderes da economia e da moda, das autoridades das religiões. E, nessa espécie de "produção" de corpos para os outros e pelos outros, fomos acordando para uma série de conflitos e contradições que nos habitavam; querendo sair das prisões que preparavam para nós, denunciamos os horrores que coletivamente nos atingiam ${ }^{14}$.

As dimensões concretas da existência, tanto as de caráter sociais quanto individuais, o que envolve as questões políticas, ecológicas, econômicas e, também, aquelas ligadas à subjetividade como a sexualidade, os valores, a afetividade, por exemplo, na grande maioria das vezes estão divorciadas das reflexões teológicas. As experiências concretas e prementes das pessoas relacionadas à vida e à morte, ligadas à sobrevivência, violência, sexualidade, pobreza e a tantos outros dramas profundos da existência e da corporeidade humana, têm sido quase sempre negligenciados pela reflexão teológica.

Ao contrário dessa visão reducionista, Rubem Alves, em sua teopoética, por exemplo, realçou a corporeidade e a tornou privilegiada nessa arte.

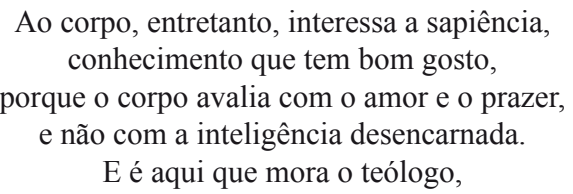

no lugar onde a palavra é corpo, poder, entidade do mundo material, chave que abre e fecha, agulha que costura as partes do mundo. ${ }^{15}$

O mesmo fez Ivone Gebara em sua teologia feminista da libertação:

O direito de suspeitar, de duvidar da "divindade" que legitima as prescrições eclesiásticas para os sujeitos femininos passou a ser moeda corrente em muitos grupos. Novas leituras da tradição começam a ser elaboradas visando dar um respaldo a partir da mesma tradição cristã às mulheres que queriam permanecer católicas e ao mesmo tempo assumir decisões pessoais no que se refere à maternidade, à regulação da natalidade, ao aborto e à oficialização das relações homossexuais ${ }^{16}$.

Se é fato que nas últimas décadas houve avanços consideráveis no que se refere às questões dos direitos das mulheres e dos grupos que vivenciam sexualidades alternativas, o enfrentamento das questões de gênero e sexualidade tem revelado que, não obstante os processos de empoderamento e mudanças sociais e culturais, há na atuali-

\footnotetext{
14 GEBARA, 2017, p. 80.

15 ALVES, 1982, p. 88.

16 GEBARA, 2017, p. 81.
} 
dade relações de poder nas quais estão sedimentadas fortes assimetrias de gênero, que se sustentam como fatores ideológicos justificadores de desigualdades compreendidas em geral como "normalidade". Evidências disso são as divisões sociais do trabalho, a organização social e política dentro de critérios de heteronormatividade, formas naturalizadas de hierarquização, discriminação e violência e a invisibilidade e o silenciamento de grupos e de reflexões que tematizam a corporeidade e aspectos a ela relacionados. As religiões estão diretamente envolvidas nesse quadro, uma vez que simultaneamente reforçam as assimetrias de gênero como também são palco de desconstrução da cultura de violência contra as mulheres, sendo componente de empoderamento e de promoção da dignidade delas, assim como de demais grupos subalternos.

E, desde já, cabe a provocação de Rubem Alves:

E não me venham com o chavão de que a preocupação com o corpo é doença de pequena-burguesia. Como se os trabalhadores não tivessem corpos, e sentissem dor de dentes com os dentes de sua classe social, fizessem amor com os genitais de sua classe social e cometessem suicídio com a decisão de sua classe social. O corpo, na verdade, é a única coisa que eles possuem - e têm de alugar. Para quem está sofrendo só existe o corpo e a dor: dor imensa, dor que é prelúdio da morte, morte que tem a ver com o meu corpo, único, irrepetível, centro do universo, grávido de deuses ${ }^{17}$.

Neste sentido, Ivone Gebara nos chama a atenção para uma nova perspectiva de fé sem que esteja baseada em deuses criados à imagem de poderes que legitimam autoridades religiosas hierárquicas.

O fato de termos contado em demasia mitos criacionais e salvíficos desde o alto ou desde a vontade dos deuses, sem respeitar o caráter antropológico simbólico de sua constituição, levou-nos a deixar o nosso destino, ou melhor, a nossa história, nas mãos dos deuses e de seus representantes. Reassumir nossa responsabilidade humana, tentar amar de novo os seres humanos na sua beleza e fealdade $[\ldots]^{18}$.

O princípio pluralista, como temos elucidado, realça que as dimensões antropológicas requerem uma nova linguagem teológica, forjada nas expressões da corporeidade, da sexualidade e dos desejos humanos, associadas às dimensões lúdicas e místicas de formas de vida marcadas pela alteridade, pela amizade gratuita, pela afirmação da diferença, pela poesia e pelo empoderamento de grupos subalternizados como os de homossexuais, indígenas, trabalhadoras e trabalhadores rurais, grupos de base especialmente de mulheres, pessoas negras e jovens, que em geral expressam, nos entrelugares de suas culturas, formas plurais de vida.

Tal visão gera formas de espiritualidades que expressam as mudanças e os processos do corpo, o que realça novas possibilidades de autoafirmação das pessoas e de grupos envolvidos e, ao mesmo tempo, reforça horizontes mais amplos para as

\footnotetext{
17 ALVES, 1982, p. 33.

18 GEBARA, 2017, p. 209.
} 
indicações de compromissos sociais e atividades políticas. Consideramos que o princípio pluralista contribui para melhor identificação de tais possibilidades.

\section{Teologia, corporeidade e sexualidade}

Afirmamos que a experiência da reflexão e da formação teológica em nossas terras quase sempre não foi estabelecida a partir dos aspectos concretos da vida. Mesmo os setores orientados pela teologia da libertação apresentaram dificuldades com o passo metodológico popularmente conhecido como "ver", que busca o fazer teológico a partir da realidade. Poderíamos dizer com certa precisão que, no caso da dimensão corpórea, ela está totalmente fora dos processos de formação teológica. O mesmo podemos dizer em relação à reflexão teológica, com raríssimas exceções. Debatem-se doutrinas e conceitos, mas o corpo, em sua existência integral e concreta, em sua mediação com a natureza, a sociedade e os outros corpos, em regra, é desprezado pela produção e pela reflexão teológica. A supremacia da dimensão conceitual em detrimento da concretude da vida é marca, a meu ver, bastante negativa dos processos de reflexão e de educação teológica. Apesar dos esforços que buscam superar tais equívocos, considero que ainda não tenha sido encontrada uma metodologia capaz de articular a dimensão corpórea da vida, com seus sabores e dissabores, com o conjunto da reflexão teológica.

Rubem Alves, ao contrário, já nos lembrara, com o veio poético que lhe é peculiar, que:

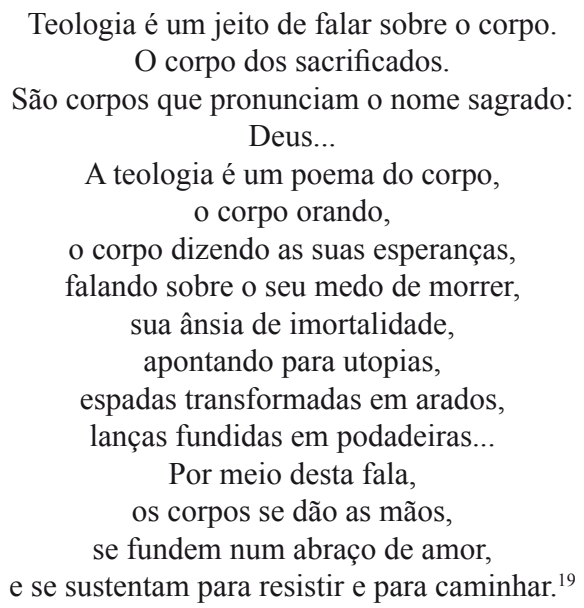

O autor propõe um desnudamento da teologia. Ele afirma que a nossa jornada é

nada mais do que brincar com símbolos, fazendo improvisações em torno de temas dados. Parecemos voar? Apenas saltos, pois nossos pés só deixam o chão por curtos

19 ALVES, 1982, p. 9. 
e fugazes momentos. E a teologia se desnudaria como coisa humana que qualquer um poderia fazer, se sentisse o fascínio dos símbolos, o amor pelo tema, e tivesse a imaginação sem a qual os pés não se despregam da terra [...] E o teólogo se redescobriria, não mais vestido com as cores fulgurantes dos que estão em cima, mas na tranquila nudez daqueles que, como os demais, andam pelos caminhos comuns da existência ${ }^{20}$.

Rubem Alves advoga a importância do prazer e da alegria e a valorização da corporeidade, não somente no tocante à reflexão teológica, mas para a educação como um todo. Com sua teologia da corporeidade, o autor nos mostra que o propósito da educação é o de "aumentar as possibilidades de prazer e alegria" 21 . Ela pode seguir nessa direção ao fazer com que o corpo, e não somente as dimensões de racionalidade, seja o ponto condutor do humano ao seu sentido maior.

Aqui reside, como defendemos a partir do princípio pluralista, um pluralismo antropológico, uma vez que se realçam outras formas de orientação humana, que não sejam reféns da razão instrumental, pragmática e mecanicista. Da mesma forma, o pluralismo antropológico que os processos teológicos devem considerar deve ser um elemento crítico das formas religiosas enrijecidas e castradoras do prazer, tão comuns nos grupos religiosos, e criativo o suficiente para cooperar nos processos de valorização da corporeidade, da sexualidade e do prazer. Trata-se, para o autor, da ressurreição dos corpos, reconciliados com o prazer e a alegria.

E o que o corpo sabe e tem a dizer à teologia? Rubem Alves realça que o corpo é uma unidade inteligente, "sabe sem precisar saber. O corpo é sábio. O corpo é educador por graça, de nascimento. Não precisa de aulas de pedagogia"22.

Em direção similar, mas com maior contundência, Marcella Althaus-Reid utiliza o método da suspeita sexual, instrumento interpretativo pelo qual a autora aplica a linguagem sexual por meio de metáforas criando uma ruptura epistemológica visando a uma nova forma de se pensar teologicamente. ${ }^{23} \mathrm{O}$ método requer a "capacidade de subverter os códigos teológicos, religiosos a partir do resgate da imagem de Deus - desde os códigos sexuais, do pulsar da vida, dos desejos e da naturalidade do cotidiano" 24 .

As teologias sexuais são o oposto dos processos idealistas. São teologias materialistas com ponto de partida nas ações humanas ou nos atos sexuais, sem deduzir o social do simbólico. É desde a sexualidade humana que a teologia começa a buscar e compreender o sagrado, não o contrário. ${ }^{25}$

\footnotetext{
20 ALVES, 1982, p. 29.

21 ALVES, Rubem. Variações sobre o prazer. 2. ed. São Paulo: Planeta, 2014. p. 84.

22 ALVES, 2014, p. 78.

${ }^{23}$ BOEHLER, Genilma. Quando elas se beijam, o mundo se transforma: o erótico em Adélia Prado e Marcella Althaus-Reid. Rio de Janeiro: Metanóia, 2013. p. 121.

24 BOEHLER, 2013, p. 128.

25 ALTHAUS-REID, Marcella. Indecent Theology: theological perversions in sex, gender and politics. London; New York: Routledge, 2000. p. 193. Tradução livre, assim como a dos demais trechos desta obra que estão a seguir.
} 
O círculo hermenêutico da suspeita sexual articula-se em dois eixos fundamentais: o da sexualidade e o do erotismo.

As teologias sexuais indecentes não necessitam de teleologia nem de sistemas, mas podem ser efetivas enquanto representam a ressurreição do excessivo nos nossos contextos e uma paixão por organizar as transgressões luxuriosas do pensamento teológico e político. O excesso de nossas famélicas vidas: nossa fome de comida, de contato com outros corpos, de amor e de Deus; uma multidão de fomes jamais satisfeitas que crescem e se estendem, e nos colocam em desafios e situações de riscos [...], de opções hermenêuticas re-torcidas no caminho de pensar teologia, política e gênero a partir de nossas experiências sexuais e de nossas identidades. ${ }^{26}$

A proposição da autora é a indecentização da teologia. Ou, no dizer de Musskopf, trata-se de sexualizar "uma teologia dessexualizada, cujo pressuposto fundador é de que toda teologia é, consciente ou inconscientemente, uma práxis sexual, organizando economicamente as relações amorosas" ${ }^{27}$. Para Marcella Althaus-Reid, por exemplo:

O imaginário da Virgem na América Latina constitui a permanente dicotomia entre desejo e amor: daí que as pobres sejam apresentadas como decentes na Teologia da Libertação, ou seja, assexuadas ou esposas heterossexuais monógamas unidas no sacramento do matrimônio, gente de fé e esforçada que não se masturba, que não acolhe pensamentos lascívios [sic] no momento da oração e que não gosta de transvertir-se $[\ldots . .]^{28}$.

A exemplo de Marcella Althaus-Reid, André Musskopf, ao fazer o uso de metáforas, de relatos de histórias sexuais e da recriação de expressões do campo teológico tensionadas com a realidade cotidiana e com os entrelugares das culturas, oferece novos sentidos e significados para a teologia. Daí a sua proposição criativa da teologia como via(da)gem. Para ele, trata-se daquilo

que está nos limites externos do pensável, como aquele espaço onde a ambiguidade se expressa como ocupação e resistência, capaz de driblar as regras e subverter o sistema heterolíneo de produção teológica. Via(da)gem como expressão concreta dos corpos e das relações que ocupam, resistem e produzem não só uma outra teologia, mas outras formas de vida em sociedade, aliando lutas tão diversas quanto a reforma agrária, os direitos sexuais e reprodutivos e o fim do racismo, da xenofobia e da exploração utilitarista e predatória do meio ambiente, seus seres e seus recursos ${ }^{29}$.

O autor enfatiza, em sua produção teológica, o relato das histórias de vida como resgate e recriação da forma de gays e lésbicas verem e enfrentarem o mundo,

${ }^{26}$ ALTHAUS-REID, 2000, p. 200.

${ }^{27}$ MUSSKOPF, 2012, p. 293.

${ }^{28}$ ALTHAUS-REID, 2000, p. 65-66.

${ }^{29}$ MUSSKOPF, André Sidney. Via(da)gens teológicas: itinerários para uma Teologia Queer no Brasil. São Paulo: Fonte Editorial, 2012. p. 463. 
emergirem como sujeitos de suas próprias realidades e construírem uma teologia que responda a tais vivências.

Assim como na Teologia Feminista, o compartilhar das histórias invisíveis é o meio para sair da escuridão e "iluminar" um mundo medido pela norma masculina, branca, heterossexual e de classe média. Embora muitas vezes não seja considerada uma forma autêntica de fazer teologia, campo ainda dominado por padrões de objetividade e universalismo, é na subjetividade e na particularidade do contar histórias de vida que gays e lésbicas podem recuperar o seu passado de opressão e discriminação, curando profundas feridas deixadas por esse passado; podem permitir a vida significar e fazer frente ao sistema que oprime e marginaliza através da formação da consciência coletiva, despertada pelo paralelismo presente nestas histórias, emergindo como sujeitos de si mesmos e de seu futuro. Esse processo dá-se como um reescrever da história. ${ }^{30}$

As metodologias inovadoras das teologias feministas e queer vão muito além da recriação das histórias de vida. Elas interagem com diferentes tradições teológicas, recriando elementos libertadores, boa parte das vezes ocultos nas interpretações teológicas e religiosas mais formais e hierarquizadas. Musskopf, por exemplo, dialoga com a teologia protestante-luterana da graça. Ele chama a atenção para o dado que na teologia cristã a

justificação que procede de Deus é algo externo ao ser humano, que depende única e exclusivamente da obra de Cristo tomando os pecados do mundo sobre si. Este é um evento que atinge todas as pessoas, pois todas pecaram e carecem da graça de Deus ( Rm 3.10,23). Descobrir esta realidade pode ajudar homens gays a sentirem-se íntegros diante de Deus, ainda que a sociedade condene a sua existência em seu mais íntimo aspecto. Eles, então, ao invés de sentirem-se condenados e rejeitados pela sociedade, podem derivar de Deus a sua justificação, com a consciência de que são pecadores da mesma forma que todos os outros serem humanos (também heterossexuais!) e nada podem fazer para alcançar a misericórdia de Deus. Ela é graça pura ${ }^{31}$.

Aqui, estamos diante de desafios teológicos de diferentes naturezas. O aspecto metodológico é crucial. Ao refletirmos sobre as bases conceituais do princípio pluralista ao longo deste trabalho, vimos, entre outros aspectos, o valor das subjetividades humanas para o fazer teológico. Da mesma forma, a importância do cotidiano, como expressão de tradução das visões de mundo, das expressões de gratuidade e de amizade, dos limites e das possibilidades humanas. Vimos também como as vivências de fronteiras - e a sexualidade como vista aqui é experiência fronteiriça, sobretudo de gêneros - fazem emergir novos sujeitos, novas reinscrições na história e formas criativas de empoderamento. ${ }^{32}$

\footnotetext{
${ }^{30}$ MUSSKOPF, 2015, p. 29

${ }^{31}$ MUSSKOPF, 2015, p. 117.

${ }^{32}$ Cf. BHABHA, 2001.
} 


\section{Considerações finais}

A pesquisa procurou identificar bases conceituais que introduzem criticamente na teologia latino-americana o valor de dimensões antropológicas que estão em torno da corporeidade, da sexualidade e do prazer, em geral desprezadas pelas leituras teológicas hegemônicas. Metodologicamente, estabelecemos a interação do princípio pluralista com a produção teológica feminista e queer latino-americanas, especialmente as de Ivone Gebara, Marcella Althaus-Reid e André Musskopf, e a teopoética de Rubem Alves.

O contexto desta análise são as reflexões sobre o princípio pluralista, que têm sido efetuadas a partir do enfrentamento de, pelo menos, três desafios, interligados entre eles, que emergem da situação teológica latino-americana: i) melhor compreensão da complexidade da realidade socioeconômica e cultural, ii) equacionamento mais adequado das relações entre racionalidade e subjetividade, e iii) os encontros e desencontros da teologia com a pluralidade, seja metodológica, religiosa ou antropológica.

Nossa intenção foi destacar aspectos de novas linguagens teológicas, forjadas nas expressões da corporeidade, da sexualidade e dos desejos humanos, e associadas às formas de vida marcadas pela alteridade, pela afirmação da diferença, pela poesia e pelo empoderamento de grupos subalternizados que, nos entrelugares de suas culturas, revelam visões plurais e criativas de vida.

Realçamos que a reflexão teológica sobre corporeidade, sexualidade e prazer tem o seu histórico na contribuição das teologias feministas e queer, sobretudo as formuladas no contexto latino-americano. $\mathrm{O}$ debate em torno desses aspectos deve ser um tributo ao salto qualitativo dado por essas teologias nessas complexas temáticas. Vimos que as definições do corpo e das práticas sexuais, explícitas ou não, quer sejam vivenciadas em contextos de prazer, autenticidade, afeto e festividade, quer em formas sublimadas, repressivas e violentas, são bases constituintes e definidores da realidade e se revelam nas fronteiras e entrelugares das culturas. Daí a importância delas para a reflexão teológica dentro do princípio pluralista. Da mesma forma, destacamos o valor das teologias narrativas e da teopoética, que representam visões de recriação da linguagem teológica, com elementos simbólicos e de forte apelo existencial que traduzem concepções teológicas fundamentais da fé.

Procuramos seguir na trilha de pensar a vida e as experiências religiosas a partir do lugar criativo e propositivo dos entrelugares e das fronteiras das culturas, assim como estar atentos à perspectiva dos estudos culturais decoloniais que destaca a tríplice demanda de decolonialidade do poder, do saber e do ser. Para isso, nos esforçamos em articular o princípio pluralista com visões antropológicas em torno da sexualidade, da corporeidade do prazer, uma vez que tais dimensões nem sempre são realçadas nas análises teológicas e constituem intensa força mobilizadora da vida.

\section{Referências}

ALTHAUS-REID, Marcella. Indecent Theology: theological perversions in sex, gender and politics. London; New York: Routledge, 2000. 
ALVES, Rubem. Variações sobre a vida e a morte: a teologia e sua fala. São Paulo: Paulinas, 1982. ALVES, Rubem. Variações sobre o prazer. 2. ed. São Paulo: Planeta, 2014.

BHABHA, Homi K. O Local da Cultura. Belo Horizonte: UFMG, 2001.

BOEHLER, Genilma. Quando elas se beijam, o mundo se transforma: o erótico em Adélia Prado e Marcella Althaus-Reid. Rio de Janeiro: Metanóia, 2013.

GEBARA, Ivone. Mulheres, religião e poder: ensaios feministas. São Paulo: Terceira Via, 2017. MIGNOLO, Walter. Delinking. The rhetoric of modernity, the logic of coloniality and the grammar of de-coloniality. Cultural studies, Abingdon-on-Thames: Routledge, v. 2 and 3, n. 21, p. 449-514, March/May 2007.

MIGNOLO, Walter. Desobediência epistêmica: a opção descolonial e o significado de identidade em política. Cadernos de Letras da UFF - Dossiê: literatura, língua e identidade, Niterói, n. 34, p. 287-324, 2008.

MIGNOLO, Walter. Histórias locais - Projetos globais: colonialidade, saberes subalternos e pensamento liminar. Belo Horizonte: UFMG, 2003.

MUSSKOPF, André Sidney. Via(da)gens teológicas: itinerários para uma Teologia Queer no Brasil. São Paulo: Fonte Editorial, 2012.

MUSSKOPF, André Sidney. Uma brecha no armário: propostas para uma teologia gay. São Paulo: Fonte Editorial; São Leopoldo: CEBI, 2015.

RIBEIRO, Claudio de Oliveira. Testemunho e Libertação: a teologia latino-americana em questão. São Paulo: Fonte Editorial, 2016.

RIBEIRO, Claudio de Oliveira. O Princípio pluralista: bases teóricas, conceituais e possibilidades de aplicação. Revista de Cultura Teológica, v. XXV, n. 90, p. 234-257, 2017.

RIBEIRO, Claudio de Oliveira. O Princípio pluralista. Cadernos de Teologia Pública - IHU, XVI, v. 14, n. 128, 2017.

SANTOS, Boaventura de Sousa. A gramática do tempo: para uma nova cultura política. São Paulo: Cortez, 2010. 